\title{
Clinical Implication of the Relationship Between High Mobility Group Box-1 and Tumor Differentiation in Hepatocellular Carcinoma
}

\author{
KEI ANDO ${ }^{1}$, MASAHIKO SAKODA ${ }^{1}$, SHINICHI UENO ${ }^{2}$, KIYOKAZU HIWATASHI ${ }^{1}$, SATOSHI IINO ${ }^{1}$, \\ KOJI MINAMI ${ }^{1}$, YOTA KAWASAKI ${ }^{1}$, MOTOYUKI HASHIGUCHI ${ }^{1}$, KIYONORI TANOUE ${ }^{1}$, YUKO MATAKI ${ }^{1}$, \\ HIROSHI KURAHARA ${ }^{1}$, KOSEI MAEMURA ${ }^{1}$, HIROYUKI SHINCHI ${ }^{3}$ and SHOJI NATSUGOE ${ }^{1}$ \\ ${ }^{1}$ Department of Digestive Surgery, Breast and Thyroid Surgery, \\ Graduate School of Medical and Dental Sciences, Kagoshima University, Kagoshima, Japan; \\ ${ }^{2}$ Department of Clinical Oncology, Graduate School of Medical and Dental Sciences, \\ Kagoshima University, Kagoshima, Japan; \\ ${ }^{3}$ Kagoshima University Graduate School of Health Sciences, Kagoshima, Japan
}

\begin{abstract}
Background/Aim: High mobility group box-1 (HMGB1) induces the release of proinflammatory cytokines and chemokines as a late-acting mediator of inflammation. Hepatocellular carcinoma (HCC) is a typical inflammationrelated cancer. However, little is known about the relationship between $H C C$ and $H M G B 1$ and its receptor $R A G E$ (receptor for advanced glycation end products). This study analyzes the clinicopathological relevance of $H M G B 1$ expression level and the effect of HMGB1 expression on the characteristics of HCC. Materials and Methods: Samples from 75 HCC patients including 13 with positive hepatitis $B$ surface antigen and 36 with hepatitis $C$ antibody were studied. The expression of HMGBI in paired cancer and non-cancerous tissues from patients with HCC was assessed using reverse-transcription polymerase chain reaction ( $R T$ $P C R)$ and western blotting. Quantitative RT-PCR data were analyzed in association with the clinicopathological factors of patients with HCC. Results: The expression of HMGBI mRNA in HCC was high in well-differentiated tumors, but declined as tumors dedifferentiated to moderately and poorly differentiated HCC. The levels of HMGBI mRNA showed a negative correlation with the presence of portal invasion $(p=0.005)$ and the rise of serum PIVKA-II $(p=0.034)$. There
\end{abstract}

Correspondence to: Masahiko Sakoda, MD, Ph.D., Department of Digestive Surgery, Breast and Thyroid Surgery, Graduate School of Medical and Dental Sciences, Kagoshima University, 8-35-1 Sakuragaoka, Kagoshima, 890-8520, Japan. Tel: +81 992755361, Fax: +81 992657426, e-mail: sakoda@m.kufm.kagoshima-u.ac.jp

Key Words: Hepatocellular carcinoma, hepatic resection, HMGB1, RAGE, tumor differentiation. was no clear correlation between HMGBI expression and proliferation activity of HCC using Ki-67 staining. Conclusion: In HCC, HMGBI expression level correlated inversely with tumor differentiation. The RAGE-HMGBI interaction may play a greater role in the early stages of HCC tumorigenesis than during cancer development.

Although many cancers arise from chronic inflammation, the relationships between carcinogenesis, cancer promotion, and its molecular characteristics remain poorly understood. Hepatocellular carcinoma (HCC), a typical inflammationrelated tumor, is one of the most common malignancies in the world, especially in Asia and Africa. Japan has high incidences of chronic viral hepatitis, cirrhosis, and HCC. The details of inflammatory activity at the molecular level may be relevant in preventing hepatocarcinogenesis and promoting cancer.

High mobility group box-1 (HMGB1) protein was first recognized as one group of chromatin-associated proteins with high acidic and basic amino acid content and is composed of three domains (1). Its function as a cytokine-like factor is activated upon translocation from the cytoplasm into the nucleus where it binds DNA and regulates transcription (2). HMGB1 functions as a late mediator in various inflammatory processes (3). In its role as a late-acting mediator of inflammation, HMGB1 induces the release of proinflammatory cytokines and chemokines such as interleukin (IL)-12, IL-6, IL-1 $\alpha$, TNF- $\alpha$, and IL-8 (4-6) by stimulating toll-like receptor ligands or LPS, TNF- $\alpha$, and IL$1 \beta$ (7) from macrophages $(8,9)$, dendritic cells $(10)$, and natural killer cells (11). These cytokines cause diseases, including cancer (12-19), sepsis (9), arthritis (20), Alzheimer's disease (21), and ischemia-reperfusion injury (22). 
Several receptors regarding HMGB1 have been identified, such as receptor for advanced glycation end products (RAGE), Toll-like receptor (TLR)2, and TLR4 (23) and thrombomodulin (24). Blocking the RAGE-HMGB1 interaction decreases tumor growth and metastasis, and suppresses the activation of $\mathrm{p} 44 / \mathrm{p} 42, \mathrm{p} 38$, and SAPK/JNK MAP kinases (25), whereas it induces the phosphorylation of extracellular signal-regulated kinase (ERK) and nuclear translocation of nuclear factor (NF)-KB (26). TLR2 and TLR4 are also involved in HMGB1-induced NF-kB activation and neovascularization (22, 27-29). These molecular mechanisms are linked to cancer proliferation, invasion, and expression of matrix metalloproteinases.

The HMGB1-RAGE interaction has been demonstrated to promote various cancers, such as gastric cancer (12), colon cancer $(13,14)$, breast cancer $(15)$, cutaneous malignancy $(16,17)$, and prostate cancer $(18)$. We previously reported that the expression of $R A G E$ mRNA, the representative receptor of HMGB1, was lower in normal liver than in hepatitis and higher than in HCC. The RAGE mRNA expression level was high in well-differentiated and moderately differentiated tumors but decreased in poorly differentiated HCC. RAGE mRNA was also upregulated in carcinogenesis but downregulated during HCC development (19). Moreover, hypoxia-resistant HCC cell lines had higher levels of RAGE expression, and significantly prolonged survival under hypoxia. Thus, the RAGE-HMGB1 interaction in HCC may have a function in the early stage of tumorigenesis and differ from the potential mechanism employed in other cancers. Ki-67 is a nuclear antigen present only in proliferating cells. A detailed cell-cycle analysis showed that the Ki-67 antigen is expressed in cells during the $\mathrm{G}_{1}, \mathrm{~S}$, and $\mathrm{G}_{1}-\mathrm{M}$ phases, but not during the $\mathrm{G}_{0}$ phase of the cell cycle (30). This study examined cell proliferation activity of HCC and the relationship with HMGB1 expression by examining the expression of Ki-67. The clinicopathological relevance of the level of HMGB1 expression in patients with $\mathrm{HCC}$ was also examined.

\section{Materials and Methods}

Human samples. From October 2000 to December 2009, 110 patients with primary HCC were treated surgically in the Department of Surgical Oncology and Digestive Surgery, Kagoshima University. Of these 110 patients, 23 who had diabetes mellitus and 7 who underwent preoperative therapy were excluded from the study according to the results of our previous study (19) because RAGE expression is up-regulated in various tissues from patients with Diabetes $(31,32)$. Another five patients were excluded because their RNA samples were degraded. Samples from the remaining 75 patients ( 55 men and 20 women with a mean age of 68.2 years) were included in this study. Thirteen patients $(17.3 \%)$ were positive for hepatitis B surface antigen and $36(48.0 \%)$ were positive for the antibody to hepatitis $\mathrm{C}$ virus. Twenty-five patients $(33.4 \%)$ were negative for both of these viruses and 1 patient $(1.3 \%)$ was positive for both of these viruses. Thirty-three patients had chronic hepatitis and 31 had liver cirrhosis. The mean tumor size was $51.8 \mathrm{~mm}$ (range $=13-150 \mathrm{~mm}$ ). The histological grade of each tumor was determined according to the General Rules for the Clinical and Pathological Study of Primary Liver Cancer (The Liver Cancer Study Group of Japan, 2000). Fourteen tumors (18.6\%) were well-differentiated HCC, $53(70.7 \%)$ moderately differentiated HCC, and $8(10.7 \%)$ poorly differentiated HCC.

Postoperative tumor recurrence was observed in 37 patients (49.3\%). As a control study, 7 normal liver samples were collected from patients with benign or metastatic liver tumors. Before tissue acquisition, each patient provided written informed consent in a form recognized by the ethical committees of Kagoshima University School of Medicine.

Immunoblot analysis. Protein samples were prepared according to the Santa Cruz protocol. Lysates $(30 \mu \mathrm{g})$ were subjected to immunoblot analysis using a $12.5 \%$ sodium dodecyl sulfate (SDS) -polyacrylamide gel followed by electrotransfer onto nitrocellulose filters. The filters were immunoreacted with an anti-HMGB1 antibody (SIGMA-ALDRICH, St. Louis, USA) and then incubated with peroxidase-conjugated anti-goat $\operatorname{IgG}$ (Medical and Biological Laboratories, Nagoya, Japan). The immune complex was visualized using an enhanced chemiluminescence western blot detection system (Pierce, Rockford, IL, USA). The amount of b-actin was also examined as an internal control using a specific antibody (SigmaAldrich, St. Louis, USA). At least three independent experiments were performed.

Quantitative RT-PCR. For reverse transcription-polymerase chain reaction (RT-PCR) and real-time quantitative PCR, total RNA was extracted from $30 \mathrm{mg}$ frozen tissue using a Total RNA Mini Kit (VIOGENE, CA, USA). For cDNA synthesis, RNA samples $(1 \mu \mathrm{g})$ were converted to cDNA by reverse transcription using random primers (TAKARA, Shiga, Japan) according to the manufacturer's instructions. To estimate the mRNA expression levels of several genes quantitatively, PCR amplification was performed using a Light-Cycler instrument system (Roche, Mannheim, Germany) and the LightCycler Fast Start DNA Master SYBR green I kit (Roche). Primers were as follows: HMGB1 5'-GCT CAG AGA GGT GGA AGA CCA3' and 5'-GGT GCA TTG GGA TCC TTG AA-3' (21), GAPDH 5'TTG GTA TCG TGG AAG GAC TCA-3' and 5'-TGT CAT ATT TGG CAG GTT T-3'. Amplification was carried out in $20 \mu 1$ reactions containing $4 \mathrm{mM} \mathrm{MgCl} 2,2 \mu \mathrm{l}$ of primers, $2 \mu \mathrm{l}$ of LightCycler Fast Start DNA Master SYBR green I reagent, and $2 \mu \mathrm{l}$ of cDNA. Reaction conditions were as follows: initial incubation at $95^{\circ} \mathrm{C}$ for $10 \mathrm{~min}$ followed by 50 cycles at $95^{\circ} \mathrm{C}$ for $10 \mathrm{sec}$ for denaturation, $54^{\circ} \mathrm{C}$ for $10 \mathrm{sec}$ for annealing of HMGB1 primers or $60^{\circ} \mathrm{C}$ for $10 \mathrm{sec}$ for annealing of GAPDH primers, and $72^{\circ} \mathrm{C}$ for $10 \mathrm{sec}$ for extension. Melting curves were obtained according to the protocol under the following conditions: $0 \mathrm{sec}$ denaturation period at $95^{\circ} \mathrm{C}$, starting temperature of $65^{\circ} \mathrm{C}$, final temperature of $95^{\circ} \mathrm{C}$, and rate of temperature increase of $0.1^{\circ} \mathrm{C}$ per sec. The quantitative value of the target gene in each sample was normalized using GAPDH expression as an internal control. The quantitative RT-PCR assay was carried out twice and the mean value was calculated. Finally, the mRNA expression ratio of cancerous $(\mathrm{C})$ to non-cancerous $(\mathrm{N})$ tissue was calculated using the following formulae: $\mathrm{R}=\log$ \{target gene (C)/GAPDH (C) $\}, \mathrm{R}=\log \{$ target gene (N)/GAPDH (N) $\}$. These experiments were carried out twice to confirm reproducibility. 


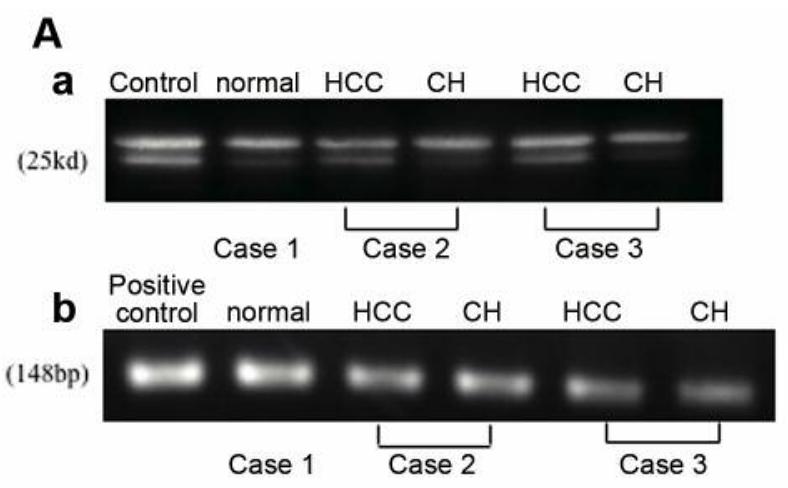

B
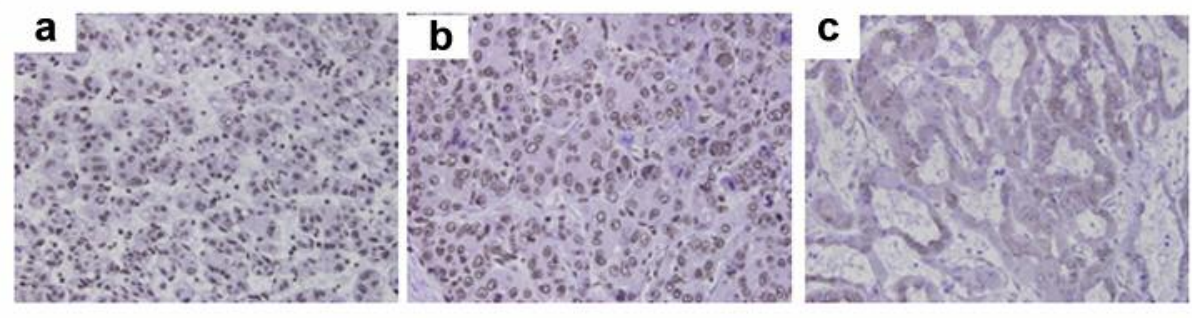

Figure 1. HMGB1 expression. (A) HMGB1 expression by western blotting (a) and RT-PCR (b). The expression in normal liver (case 1) and paired cancer and noncancerous tissues (case 2 and 3) was represented. Normal: Normal liver; CH: chronic hepatitis. (B) HMGB1 expression by immunohistochemical staining: (a) well differentiated HCC, (b) moderately differentiated HCC, (c) poorly differentiated HCC.

\begin{abstract}
Immunohistochemistry. Consecutive 4- $\mu \mathrm{m}$ sections were cut from each paraffin-embedding block. Sections were immunostained by an antiHMGB1 antibody (SIGMA, CA, USA) and anti-Ki-67 (MIB-1, Dako, Glostrup, Denmark) according to the conventional immunoperoxidase technique. After peroxidase-blocking with $3 \% \mathrm{H}_{2} \mathrm{O}_{2} /$ methanol for 10 min and autoclave treatment $\left(121^{\circ} \mathrm{C}, 10 \mathrm{~min}\right)$, specimens were blocked with phosphate-buffered saline (PBS) containing 5\% normal horse serum (Vector Laboratories, Inc., Burlingame, CA, USA). An antiHMGB 1 antibody was used at 1:200 and anti-Ki-67 was used at 1:100. After overnight incubation at $4^{\circ} \mathrm{C}$ with the primary antibody, specimens were briefly washed in PBS and incubated at room temperature with peroxidase-conjugated secondary antibody. The specimens were then washed in PBS and color-developed by diaminobenzidine solution (DAKO). After washing with water, specimens were counterstained with Meyer's hematoxylin (Sigma Chemical Co., St. Louis, MO, USA). Immunostaining of all cases was performed at one time to ensure uniform conditions of antibody reaction and $\mathrm{DAB}$ exposure. To evaluate the immunohistochemical staining, ten fields were selected and expression in all tumor cells was evaluated with high-power $(\times 200)$ microscopy.
\end{abstract}

Statistical analysis. Statistical analysis was performed using the JMP IN version 5.1.2 software system (SAS Institute Inc., NC, USA). Gene expression was compared among normal liver, hepatitis, and HCC using Student's $t$-test. The relationships between HMGB1 mRNA expression levels and clinicopathological factors were evaluated using the Student's $t$-test and the Mann-Whitney $U$-test, as appropriate. A $p$ value of less than 0.05 was considered statistically significant.

\section{Results}

HMGB1 expression in HCC. Protein and mRNA expression of HMGB1 were examined by western blotting and RT-PCR in normal liver, noncancerous, and cancerous tissues from three cases (Figure 1A). All three cases showed expression of HMGB1 protein and mRNA in these tissues. The expression of HMGB1 in tumor cells was examined by immunohistochemical staining. HMGB1 expression was observed in the nucleus (Figure 1B).

Quantitative HMGB1 mRNA expression in HCC and noncancerous lesions. Quantitative expression of $H M G B 1$ mRNA was compared in paired cancer and noncancerous tissues (i.e., tissues from patients with chronic hepatitis or liver cirrhosis) from 75 cases, and from seven normal liver cases. The mean value in cancerous tissues and noncancerous tissues tended to be higher than that in normal liver tissues, although the differences were not significant (Figure 2).

Relationship between HMGB1 mRNA expression and clinicopathological factors. To elucidate the biological significance of HMGB1 expression in HCC, the levels of HMGBl mRNA expression were compared with the 


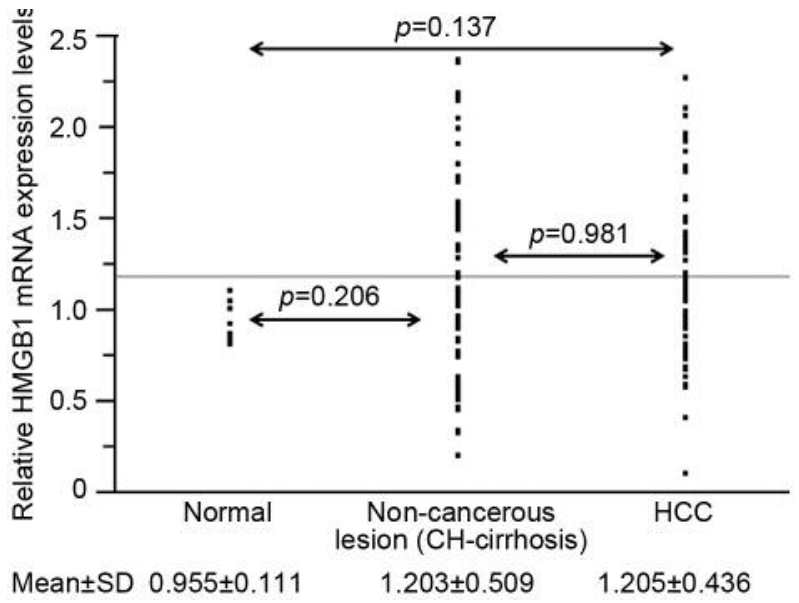

Figure 2. Quantitative expression of HMGB1 in normal liver $(n=7)$ and paired noncancerous and cancerous tissues $(n=75)$.

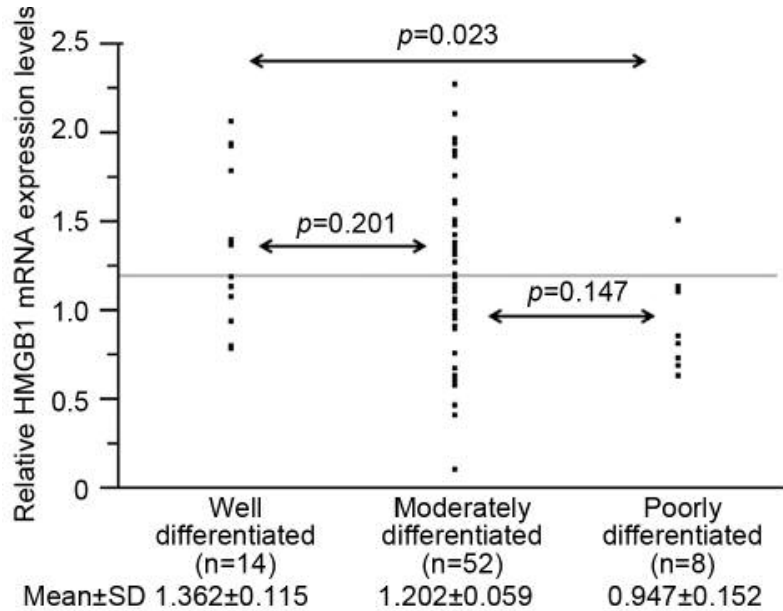

Figure 3. Quantitative expression of HMGB1 according to tumor differentiation.

clinicopathological factors of 75 patients. As shown in Table I, significant differences were noted in $H M G B 1$ mRNA expression in association with portal invasion, tumor differentiation, and elevated levels of protein induced by Vitamin $\mathrm{K}$ absence or its antagonist II (PIVKA-II). In the patients with portal vein invasion, $H M G B 1$ expression was lower than levels in patients without portal vein invasion. $H M G B 1$ expression was lower in patients with poorly differentiated HCC than in patients with well-differentiated HCC.

Relationship between HMGBI expression and proliferation activity of HCC according to tumor differentiation. When comparing HMGB1 expression according to tumor differentiation, the level of HMGB1 expression decreased as
Table I. Relationship between tumor HMGB1 expression and clinicopathologic features.

\begin{tabular}{|c|c|c|c|c|c|}
\hline \multirow[t]{2}{*}{ Factors } & \multicolumn{3}{|c|}{ HMGB1 mRNA expression } & & \multirow[t]{2}{*}{$p$-Value } \\
\hline & $\mathrm{n}$ & mean $\pm \mathrm{SD}$ & & & \\
\hline \multicolumn{6}{|l|}{ Gender } \\
\hline Male & 55 & $1.195 \pm 0.459$ & & & \multirow[t]{2}{*}{0.762} \\
\hline Female & 20 & $1.230 \pm 0.379$ & & & \\
\hline \multicolumn{6}{|l|}{ Age } \\
\hline$<65$ years & 19 & $1.236 \pm 0.481$ & & & \multirow[t]{2}{*}{0.717} \\
\hline$\geq 65$ years & 56 & $1.194 \pm 0.425$ & & & \\
\hline \multicolumn{6}{|l|}{ Viral hepatitis status } \\
\hline HBsAg, positive & 13 & $1.344 \pm 0.544$ & \multicolumn{2}{|c|}{0.211} & 0.356 \\
\hline Anti-HCV-Ab, positive & 36 & $1.164 \pm 0.398$ & 0.211 & 0.802 & 0.356 \\
\hline Non-viral & 25 & $1.190 \pm 0.443$ & & 0.802 & 0.356 \\
\hline \multicolumn{6}{|l|}{ Tumor size(mm) } \\
\hline$<30$ & 21 & $1.165 \pm 0.405$ & & & \multirow[t]{2}{*}{0.627} \\
\hline$\geq 30$ & 54 & $1.220 \pm 0.451$ & & & \\
\hline \multicolumn{6}{|l|}{ Growth form } \\
\hline Expansive & 72 & $1.212 \pm 0.435$ & & & \multirow[t]{2}{*}{0.473} \\
\hline Invasive & 3 & $1.026 \pm 0.528$ & & & \\
\hline \multicolumn{6}{|l|}{ Capsule formation } \\
\hline Absent & 8 & $1.387 \pm 0.310$ & & & \multirow[t]{2}{*}{0.215} \\
\hline Present & 67 & $1.183 \pm 0.446$ & & & \\
\hline \multicolumn{6}{|l|}{ Capsule invasion } \\
\hline Absent & 15 & $1.362 \pm 0.387$ & & & \multirow[t]{2}{*}{0.119} \\
\hline Present & 60 & $1.165 \pm 0.443$ & & & \\
\hline \multicolumn{6}{|l|}{ Septum formation } \\
\hline Absent & 11 & $1.379 \pm 0.455$ & & & \multirow[t]{2}{*}{0.152} \\
\hline Present & 64 & $1.175 \pm 0.430$ & & & \\
\hline Vascular invasion & & & & & \\
\hline Absent & 41 & $1.280 \pm 0.472$ & & & 0.099 \\
\hline Present & 34 & $1.113 \pm 0.377$ & & & \\
\hline Portal invasion & & & & & \\
\hline Absent & 44 & $1.322 \pm 0.432$ & & & 0.005 \\
\hline Present & 31 & $1.037 \pm 0.392$ & & & \\
\hline Venous invasion & & & & & \\
\hline Absent & 57 & $1.235 \pm 0.444$ & & & 0.284 \\
\hline Present & 18 & $1.108 \pm 0.408$ & & & \\
\hline Bile duct invasion & & & & & \\
\hline Absent & 70 & $1.221 \pm 0.423$ & & & 0.233 \\
\hline Present & 5 & $0.977 \pm 0.608$ & & & \\
\hline Tumor differentiation & & & & & \\
\hline Well & 14 & $1.362 \pm 0.115$ & 0.23 & & 0.025 \\
\hline Moderately & 53 & $1.202 \pm 0.059$ & 0.23 & 0.122 & 0.025 \\
\hline Poorly & 8 & $0.947 \pm 0.152$ & & 0.122 & 0.025 \\
\hline TMN stage* & & & & & \\
\hline I-II & 39 & $1.298 \pm 0.453$ & & & 0.051 \\
\hline III-IV & 36 & $1.103 \pm 0.400$ & & & \\
\hline PIVKA-II & & & & & \\
\hline Normal & 22 & $1.375 \pm 0.399$ & & & 0.034 \\
\hline High & 51 & $1.137 \pm 0.444$ & & & \\
\hline AFP & & & & & \\
\hline Normal & 29 & $1.296 \pm 0.462$ & & & 0.149 \\
\hline High & 46 & $1.147 \pm 0.415$ & & & \\
\hline Recurrence & & & & & \\
\hline Yes & 37 & $1.163 \pm 0.416$ & & & 0.522 \\
\hline No & 38 & $1.232 \pm 0.464$ & & & \\
\hline
\end{tabular}

*According to the criteria of the Liver Cancer study Group of Japan. HBsAg: Hepatitis B surface antigen; HCV: hepatitis C virus; Ab: antibody; PIVKA-II: protein induced by Vitamin $\mathrm{K}$ absence or antagonists-II; AFP: alpha-fetoprotein. 
A

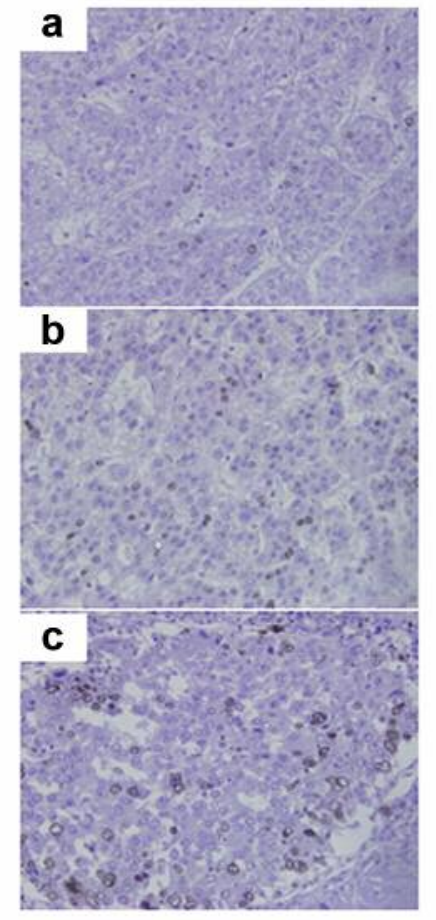

B

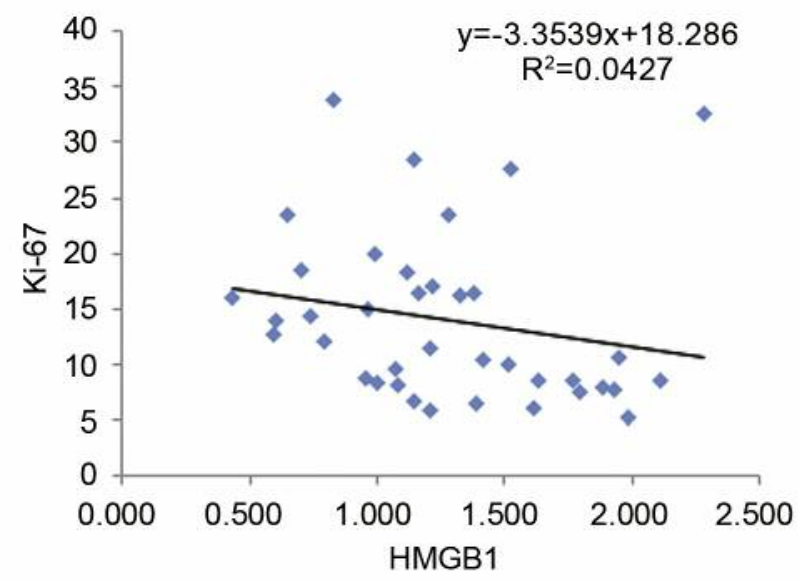

Figure 4. Ki-67 expression and relationship between HMGB1 and Ki-67. (A) Ki-67 expression by immunohistochemical staining: (a) well differentiated HCC, (b) moderately differentiated HCC, (c) poorly differentiated HCC. (B) Correlation of HMGB1 expression and proliferation activity of HCC by Ki-67 staining.

HCC became less differentiated (Figure 3). Moreover, the proliferation activity of HCC was examined by immunohistochemical Ki-67 staining (Figure 4A). The rate of Ki-67 positive cells (namely, proliferation activity of HCC) increased as HCC became less differentiated. There was no clear correlation between HMGB1 expression and proliferation activity of HCC (Figure 4B).

Relationship between HMGB1 expression in HCC and patient survival. In order to show the relationship between HMGB1 expression and patient prognosis, we divided the 75 patients were divided into 2 groups by the median level of HMGB1 mRNA expression. When comparing overall and recurrence-free survival, there were no significant differences in HMGB1 expression (Figure 5).

\section{Discussion}

When inflammatory events such as injury, infection, or cell necrosis occur, HMGB1 is secreted $(33,34)$. It induces the release of pro-inflammatory cytokines and chemokines such as p44/p42, p38, SAPK/JNK MAP kinases, ERK, and NF-kB (25). Therefore, we hypothesized that HMGB1 may play an important role in the occurrence and development of HCC, which typifies inflammation-related tumors caused by viral or alcoholic hepatitis. Results from our previous study showed the clinicopathological relevance of the RAGE mRNA expression level, the counter-receptor for $H M G B 1$, in patients with HCC (19). In that study, significant differences in $R A G E$ mRNA expression were shown according to gender, age, the level of PIVKA-II, tumor differentiation, and postoperative recurrence of HCC. In particular, the level of RAGE mRNA expression was higher in well or moderately differentiated tumors than in poorly differentiated tumors, and this result was confirmed by immunohistochemical examination. Moreover, the levels of RAGE mRNA showed an inverse correlation with the presence of recurrence.

In the present study, comparing the quantitative expression of $H M G B 1 \mathrm{mRNA}$ in paired cancerous and non-cancerous tissues (i.e. chronic hepatitis or liver cirrhosis), there was no significant difference between cancerous tissues and noncancerous tissues. The mean values of HMGBl mRNA expression in cancerous and non-cancerous tissues tended to be higher than that in normal liver tissues (i.e. non-inflamed liver from benign or metastatic liver tumor patients). Furthermore, in patients with HCC, the $H M G B 1$ mRNA level differed significantly with regard to tumor differentiation. $H M G B 1$ mRNA was expressed at lower level in poorly 

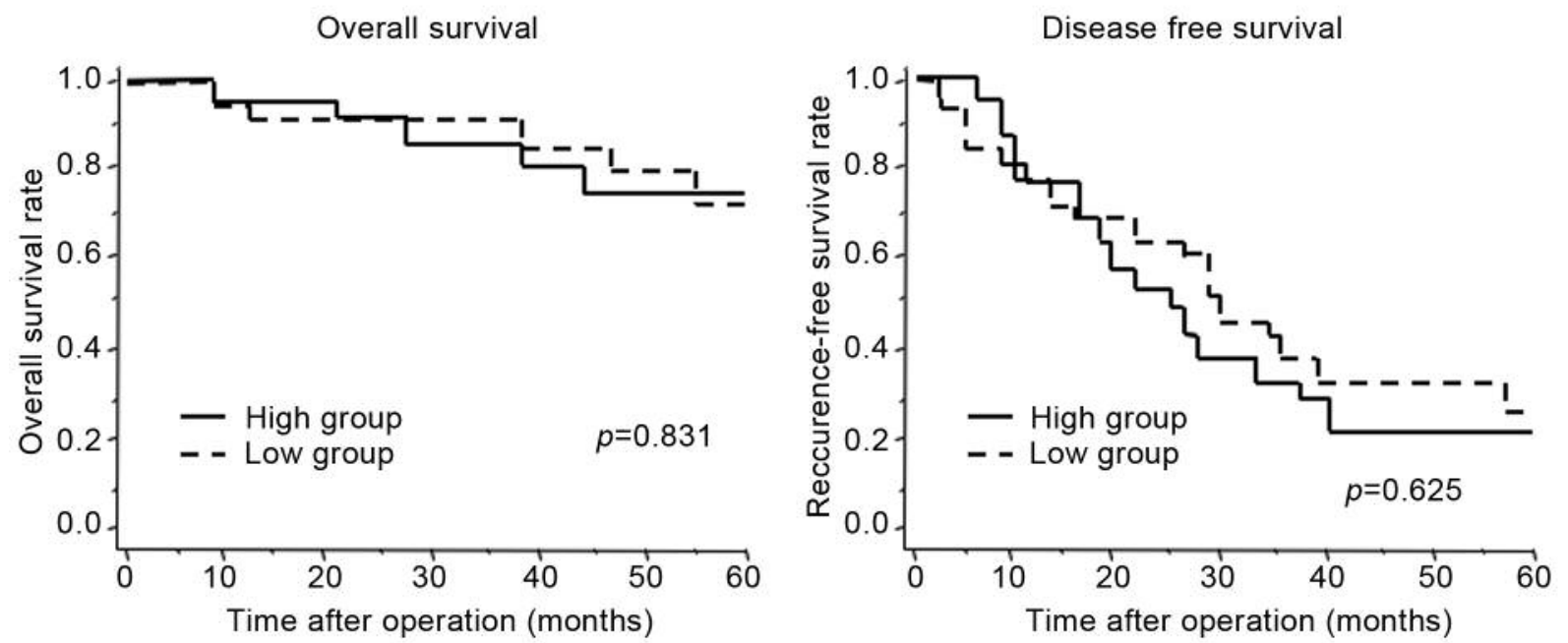

Figure 5. Relationship between HMGB1 expression in HCC and patient's survival. All patients were divided into the 2 groups by the median level of HMGB1 mRNA expression.

differentiated HCC than in well differentiated HCC $(p=0.023)$. The levels of $H M G B 1 \mathrm{mRNA}$ showed a negative correlation with the presence of the portal invasion $(p=0.005)$ and the rise of serum PIVKA-II $(p=0.034)$. These results were remarkably similar to those of our previous study of the clinicopathological relevance of the level of RAGE expression (19). Whereas HMGB1 has been demonstrated to promote various cancers, Akaike et al. evaluated expression of HMGB1 in gastric cancer and reported that the prognosis of the low HMGB1 group was significantly poorer than that of the high HMGB1 group and HMGB 1 expression revel in gastric cancer tended to be correlate inversely with depth of tumor invasion and lymph node metastasis (35). Cebrián et al. also reported in review of the biological and clinical relevance of HMGB1 in pancreatic cancer that HMGB1 exhibits a dual and paradoxical role; that is, extracellular HMGB1 becomes a pro-tumor protein, acting as cytokine, chemokine and growth factor, whereas intracellular HMGB1 functions as an antitumor protein, stabilizing the genome and sustaining autophagy (36).

Once cancer is established, HCC differentiates systematically to a more malignant histology, from well or moderately differentiated to poorly differentiated HCC. In our results, when HCC is established (and is well differentiated), HMGB1 and RAGE expression are high. This may reflect elevated tumor activity as shown in Figure 6. Evidence from clinical studies (37-39) indicate that well-differentiated HCC consists of hypovascular tumors primarily fed by the portal vein system, while moderately and poorly differentiated HCC consist of hypervascular tumors primarily fed by arterial blood. Considering the level of RAGE mRNA

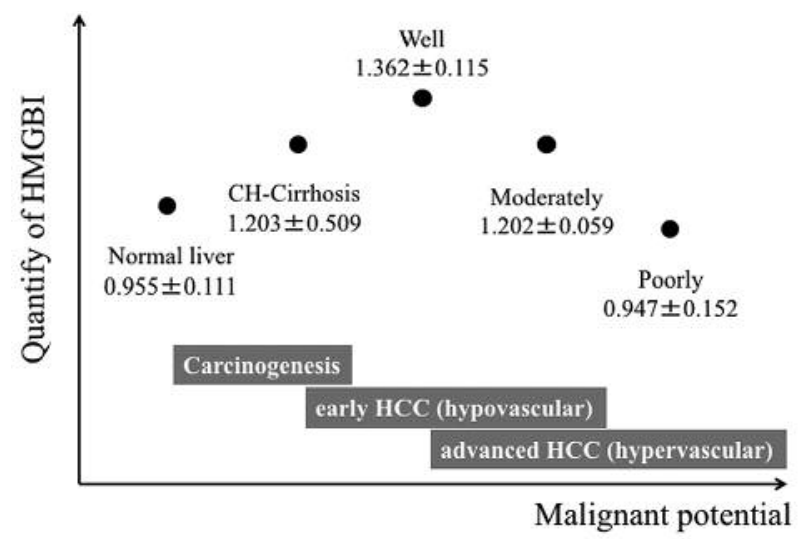

Figure 6. Scheme of the change of HMGB1 expression according to the sequential change of liver tissue: normal $\rightarrow$ chronic hepatitis $(\mathrm{CH}) \rightarrow$ cirrhosis $\rightarrow H C C$. The value indicates the quantitative HMGB1 mRNA expression.

expression in each stage of differentiation and the in vitro results, it is suggested that RAGE has a function in resistance to hypoxia. HMGB1 might be also be related to hypoxia resistance leading to the induction of angiogenic cytokines such as IL-8. The HMGB1-RAGE interaction undoubtedly plays a vital role in HCC.

In conclusion, HMGB1 expression level in HCC correlated inversely with tumor differentiation and was similar to the level that we reported previously in a study on the clinicopathological relevance of RAGE level in HCC. The RAGE-HMGB 1 interaction might work in the early stage of HCC tumorigenesis than in the stage of cancer 
development. The interaction of RAGE and HMGB1 in cancer is still poorly understood, and it is expected that further examination of their molecular mechanisms will aid in the development of new cancer therapies.

\section{Conflicts of Interest}

The Authors declare no potential conflicts of interest.

\section{References}

1 Goodwin GH, Sanders C and Johns EW: A new group of chromatin-associated proteins with a high content of acidic and basic amino acids. Eur J Biochem 38: 14-19, 1973.

2 Bianchi ME: Significant (re)location: how to use chromatin and/or abundant proteins as messages of life and death. Trends Cell Biol 14: 287-293, 2004.

3 Tsung A, Sahai R, Tanaka H, Nakao A, Fink MP, Lotze MT, Yang H, Li J, Tracey KJ, Geller DA and Billiar TR: The nuclear factor HMGB1 mediates hepatic injury after murine liver ischemia-reperfusion. J Exp Med 201: 1135-1143, 2005.

4 Dimov SI, Alexandrova EA and Beltchev BG: Differences between some properties of acetylated and nonacetylated froms of HMGB1 protein. Biochem Biophys Res Commun 166: 819826, 1990.

5 Rouhiainen A, Kuja-Panula J, Wilkman E, Pakkanen J, Stenfors $\mathrm{J}$, Tuominen RK, Lepäntalo $\mathrm{M}$, Carpén $\mathrm{O}$, Parkkinen $\mathrm{J}$ and Rauvala H: Regulation of monocyte migration by amphoterin (HMGB1). Blood 104: 1174-1182, 2004.

6 Messemer D, Yang H, Telusma G, Knoll F, Li J, Messemer B, Tracey KJ and Chiorazzi N: High mobility group box protein 1: an endogenous signal for dendritic cell maturation and Th1 polarization. J Immunol 173: 307-313, 2004.

7 Lotze MT and Tracey KJ: High-mobility group box 1 protein(HMGB 1): nuclear weapon in the immune arsenal. Nat Rev Immunol 5: 331-342, 2005.

8 Bonaldi T, Talamo F, Scaffidi P, Ferrera D, Poto A, Bachi A, Rubartelli A, Agresti A and Bianchi ME: Monocytic cells hyperacetylate chromatin protein HMGB1 to redirect it towards secretion. Embo J 22: 5551-5560, 2003.

9 Wang H, Bloom O, Zhang M, Vishnubhakat JM, Ombrellino M, Che J, Frazier A, Yang H, Ivanova S, Borovikova L, Manogue KR, Faist E, Abraham E, Andersson J, Andersson U, Molina PE, Abumrad NN, Sama A and Tracey KJ: HMG-1 as a late mediator of endotoxin lethality in mice. Science 285: 248-251, 1999.

10 Dumitriu IE, Baruah P, Valentinis B, Voll RE, Herrmann M, Nawroth PP, Arnold B, Bianchi ME, Manfredi AA and RovereQuerini P: Release of high mobility group box 1 by dendritic cells controls $\mathrm{T}$ cell activation via the receptor for advanced glycation end products. J Immunol 174: 7506-7515, 2005.

11 Semino C, Angelini G, Poggi A and Rubartelli A: NK/iDC interaction results in IL-18 secretion by DCs maturation factor HMGB1. Blood 106: 609-616, 2005.

12 Kuniyasu H, Oue N, Wakikawa A, Shigeishi H, Matsutani N, Kuraoka K, Ito R, Yokozaki $\mathrm{H}$ and Yasui W: Expression of receptors for advanced glycation end-products(RAGE) is closely associated with the invasive and metastatic activity of gastric cancer. J Pathol 196: 163-170, 2002.
13 Kuniyasu H, Chihara Y and Kondo H: Differential effects between amphoterin and advanced glycation end products on colon cancer cells. Int J Cancer 104: 722-727, 2003.

14 Ueda M, Takahashi Y, Shinden Y, Sakimura S, Hirata H, Uchi R, Takano Y, Kurashige J, Iguchi T, Eguchi H, Sugimachi K, Yamamoto H, Doki Y, Mori $\mathrm{M}$ and Mimori K: Prognostic significance of high mobility group box 1 (HMGB1) expression in patients with colorectal cancer. Anticancer Res 34: 5357-5362, 2014.

15 Flohr AM, Rogalla P, Meiboom M, Borrmann L, Krohn M, Thode-Halle B and Bullerdiek J: Variation of HMGB1 expression in breast cancer. Anticancer Res 21: 3881-3885, 2001.

16 Nguyen AH, Detty SQ and Agrawal DK: Clinical implications of high-mobility group box-1 (HMGB1) and the receptor for advanced glycation end-products (RAGE) in cutaneous malignancy: A Systematic Review. Anticancer Res 37: 1-7, 2017.

17 Poser I, Golob M, Buettner R and Bosserhoff AK: Upregulation of HMGB1 leads to melanoma inhibitory activity expression in malignant melanoma cells and contributes to their malignancy phenotype. Mol Cell Biol 23: 2991-2998, 2003.

18 Ishiguro H, Nakaigawa N, Miyoshi Y, Fujinami K, Kuboa Y and Uemura H: Receptor for advanced glycation end products(RAGE) and its ligand, amphoterin are overexpressed and associated with prostate cancer development. Prostate 64: 92-100, 2005.

19 Hiwatashi K, Ueno S, Abeyama K, Kubo F, Sakoda M, Maruyama I, Hamanoue M, Natsugoe S and Aikou T: A novel function of the receptor for advanced glycation end-products (RAGE) in association with tumorigenesis and tumor differentiation of HCC. Ann Surg Oncol 15: 923-933, 2008.

20 Taniguchi N, Kawahara K, Yone K, Hashiguchi T, Yamakuchi M, Goto M, Inoue K, Yamada S, Ijiri K, Matsunaga S, Nakajima T, Komiya $\mathrm{S}$ and Maruyama I: High mobility group box chromosomal protein 1 plays a role in the pathogenesis of rheumatoid arthritis as a novel cytokine. Arthritis Rheum 48: 971-981, 2003.

21 Takata K, Kitamura Y, Kakimura J, Shibagaki K, Tsuchiya D, Taniguchi T, Smith MA, Perry G and Shimohama S: Role of high mobility group protein-1(HMG1) in amyloid-beta homeostasis. Biochem Biophys Res Commun 301: 699-703, 2003.

22 Tsung A, Hoffman RA, Izushi K, Critchlow ND, Nakao A, Chan MH, Lotze MT, Geller DA and Billiar TR: Hepatic ischemia/reperfusion injury involves functional TLR4 signaling in nonparenchymal cells. J Immunol 1775: 7661-7668, 2005.

23 Park JS, Svetkauskaite D, He Q, Kim JY, Strassheim D, Ishizuka $A$ and Abraham E: Involvement of toll-like receptors 2 and 4 in cellular activation by high mobility group box 1 protein. J Biol Chem 279: 7370-7377, 2004.

24 Abeyama K, Stern DM, Ito Y, Yoshimoto Y, Tanaka M, Uchimura T, Ida N, Yamazaki Y, Yamada S, Yamamoto Y, Yamamoto $\mathrm{H}$, Iino S, Taniguchi $\mathrm{N}$ and Maruyama I: The Nterminal domain of thrombomodulin sequesters high-mobility group-B1 protein, a novel anti-inflammatory mechanism. J Clin Invest 115: 1267-1274, 2005.

25 Taguchi A, Blood DC, del Toro G, Canet A, Lee DC, Qu W, Tanji N, Lu Y, Lalla E, Fu C, Hofmann MA, Kislinger T, Ingram M, Lu A, Tanaka H, Hori O, Ogawa S, Stern DM and Schmidt AM: Blockade of RAGE-amphoterin signaling suppresses tumor growth and metastasis. Nature 405: 354-360, 2000.

26 Yang H, Wang H, Czura CJ and Tracey KJ: The cytokine activity of HMGB1. J Leukoc Biol 78: 1-8, 2005. 
27 Ulloa L and Messemer D: High-mobility group box 1 (HMGB1) protein: friend and foe. Cytokine Growth Factor Rev 17: 189201, 2006.

28 Mitola S, Belleri M, Urbinati C, Cltorini D, Sparatore B, Pedrazzi M, Melloni E and Presta M: Cutting edge: extracellular high mobility group box-1 protein is a proangiogenic cytokine. J Immunol 176: 12-15, 2006.

29 Frantz S, Vincent KA, Feron O and Kelly RA: Innate immunity and angiogenesis. Circ Res 96: 15-26, 2005.

30 Stroescu C, Dragnea A, Ivanov B, Pechianu C, Herlea V, Sgarbura O, Popescu A and Popescu I: Expression of p53, Bcl-2, VEGF, Ki67 and PCNA and prognostic significance in hepatocellular carcinoma. J Gastrointestin Liver Dis 17: 411-417, 2008.

31 Chen Y, Yan SS, Colgan J, Zhang HP, Luban J, Schmidt AM, Stern D and Herold KC: Blockade of late stages of autoimmune diabetes by inhibition of the receptor for advanced glycation end products. J Immunol 173: 1399-1405, 2004.

32 Wendt TM, Tanji N, Guo J, Kislinger TR, Qu W, Lu Y, Bucciarelli LG, Rong LL, Moser B, Markowitz GS, Stein G, Bierhaus A, Liliensiek B, Arnold B, Nawroth PP, Stern DM, D'Agati VD and Schmidt AM: RAGE drives the development of glomerulosclerosis and implicates Podocyte activation in the pathogenesis of diabetic nephropathy. Am J Pathol 162: 1123$1137,2003$.

33 Winter N, Meyer A, Richter A, Krisponeit D and Bullerdiek J: Elevated levels of HMGB1 in cancerous and inflammatory effusions. Anticancer Res 29: 5013-5017, 2009.

34 Nowak P, Nystrom J and Troseid M: High levels of HMGB1 in plasma may be due to ex vivo cell necrosis. Anticancer Res 32: 4067-4069, 2012
35 Akaike H, Kono K, Sugai H, Takahashi A, Mimura K, Kawaguchi $\mathrm{Y}$ and Fujii $\mathrm{H}$ : Expression of high mobility group box chromosomal protein-1 (HMGB-1) in gastric cancer. Anticancer Res 27: 449-457, 2007.

36 Cebrián MJ, Bauden M, Andersson R, Holdenrieder S and Ansari D: Paradoxical role of HMGB1 in pancreatic cancer: tumor suppressor or tumor promoter? Anticancer Res 36: 43814389, 2016.

37 Hayashi M, Matsui O, Ueda K, Kawamori Y, Kadoya M, Yoshikawa J, Gabata T, Takashima T, Nonomura A and Nakanuma Y: Correlation between the blood supply and grade of malignancy of Hepatocellular nodules associated with liver chirrhosis: evaluation by CT during intraarterial injection of contrast medium. Am J Roentgenol 172: 969-976, 1999.

38 Ueda K, Terada T, Nakanuma Y and Matsui O: Vascular supply in adenomatous hyperplasia of the liver and hepatocellular carcinoma: a morphometric study. Hum Pathol 23: 619-626, 1992.

39 Matsui O, Kadoya M, Kameyama T, Yoshikawa J, Takashima T, Nakanuma Y, Unoura M, Kobayashi K, Izumi R and Ida M: Benign and malignant nodules in cirrhotic livers: distinction based on blood supply. Radiology 178: 493-497, 1991.

Received March 18, 2018

Revised April 18, 2018

Accepted April 19, 2018 